DOI: 10.12731/wsd-2017-3-25-38

UDC 599.323.4:578.833.29(571.63)

\title{
ASSESSMENT OF EPIZOOTIC ACTIVITY AND EPIDEMIC RISK IN HEMORRHAGIC FEVER WITH RENAL SYNDROME FOREST FOCI OF PRIMORSKY KRAI ${ }^{1}$
}

\author{
Kushnareva T.V., Kumaksheva E.V.
}

In forest foci of hemorrhagic fever with renal syndrome (HFRS) of Primorsky Krai Amur and Hokkaido hantaviruses are circulated in the natural host population, i.e. Apodemus peninsulae and Myodes rufocanus. The indicators of epizootic activity and their threshold values in rodent population dynamics were determined in order to forecast HFRS outbreaks. The material for the research was obtained throughout 2001-2013. The number of trap-nights was 33890. 2737 of A. peninsulae and 1643 of M. rufocanus were investigated. ELISA, RTPCR, IFA were used for the detection of hantavirus antigen, RNA, antibodies/ avidity. The parameters of epizootic activity per $100 \mathrm{TN}\left(\mathrm{N}\right.$ - population, $n_{i}-i n-$ fected rodents, $n_{a i}$-individuals with acute infection) were proposed. The results showed that the active foci of Amur viral infection are located on the slopes of the Sikhote-Alin ridge. The epizootic activity in A. peninsulae populations is characterized by the expressed cyclicity: phase I is rise, phase II is high activity, phase III is recession/low activity. Phases I and II are valid up to a year, whereas phase III is valid within a few years, determining the whole epizootic cycle. In phase I the number of rodents with an acute infection increased from summer to late autumn. In phase II the number of rodents with acute infection was considerable in spring/summer and decreased in autumn more than 3 times. In all phases of the cycle the threshold values were considerably higher for A. peninsulae, than for M. rufocanus, thus showing the former's epidemiological role in forest ecosystems. HFRS infection rate in phases I/II of the epizootic cycle in A. peninsulae populations had two peaks: during late autumn - winter $(\geq 37 \%$ of cases) and spring - first half of summer ( $\geq 55 \%$ of cases).

${ }^{1}$ Кушнарева Т.В., Кумакшева Е.В. Оценка эпизоотической активности и эпидемического риска в лесных очагах геморрагической лихорадки с почечным синдромом Приморского края // В мире научных открытий, 2016. № 6(78). С. 92-108. doi:10.12731/wsd-2016-6-6. 
The obtained threshold values of Amur hantavirus active circulation in population dynamics of the natural host allows to predict the periods of the increased risk of infection in HFRS forest foci for humans.

Keywords: hantaviruses; rodents; hemorrhagic fever with renal syndrome (HFRS); natural foci; Primorsky Krai.

\section{ОЦЕНКА ЭПИЗООТИЧЕСКОЙ АКТИВНОСТИ И ЭПИДЕМИЧЕСКОГО РИСКА В ЛЕСНЫХ ОЧАГАХ ГЕМОРРАГИЧЕСКОЙ ЛИХОРАДКИ С ПОЧЕЧНЫМ СИНДРОМОМ ПРИМОРСКОГО КРАЯ}

Кушнарева Т.В., Кумакшева Е.В.

В лесных очагах геморрагической лихорадки с почечным синдромом (ГЛПС) Приморского края цииркулируют хантавирусы Amur и Hokkaido в популяииях природных хозяев - Apodemus peninsulae и Myodes rufocanus. С иелью прогноза подъемов заболеваемости ГЛПС определены индикаторные показатели эпизоотической активности и их пороговые значения в динамике популяций грызунов. Материал получен в 2001-2013 г2. Выставлено 33890 ловушко-ночей (л-н). Исследовано 2737 A. peninsulae и 1643 M. rufocanus. Антиген, РНК хантавируса, специфические антитела / авидность вылвляли в ИФА, ОТ-ПЦР, НМФА. Предложены показатели эпизоотической активности на 100 л-н: $N$ - вся популяция; $n_{u}$ все инфицированные; $n_{\text {ои }}$ все особи с острой инфекциией. Результаты показали, что активные очаги Атиг-вирусной инфекции расположены на склонах хребта Сихотэ-Алинь. Эпизоотическая активность в популяциях A. peninsulaе имеет выраженную иикличность: I фаза-подъем, II - высокая, III - спад / низкая активность. I и II фазы длятся не более года, III фаза длится несколько лет, определяя период всего эпизоотического ичикла. В I фазу число зверьков с острой инфекцией увеличивалось от лета к поздней осени. Во II число зверьков с острой инфекцией было значительно выше весной/летом, снижаясь осенью более чем в 3 раза. Значения показателей во все фазы иикла были значительно выше у А. peninsulae, чем у M. rufocanиs, указывая на ее эпидемическую значимость в лесных экосистемах. В период I и II фаз эпизоотического ичикла в популяииях A. peninsulae заболеваемость ГЛПС в крае имела два пика: осенне-зимний ( $\geq 37 \%$ случаев) и весенне-летний $(\geq 55 \%$ случаев). 
Полученные пороговые показатели активной циркуляции вируса Атиг в динамике популяиий природного хозяина дают возможность прогнозировать периоды повышенного риска заражения людей в лесных очагах ГЛПС.

Ключевые слова: хантавирусы; грызуны; геморрагическая лихорадка с почечным синдромом (ГЛПС); природные очаги; Приморский край.

\section{Introduction}

Currently, over 40 genetically and immunologically distinct hantavirus species in the genus Hantavirus of the Bunyaviridae family have been discovered. Each of them, with few exceptions, is strongly associated with a unique host species, having passed a long way of co-evolution. 22 species of hantaviruses are considered pathogenic to humans, their natural hosts being defined as the rodents of the three families, i.e. Murinae, Cricetinae, Sigmodontinae [1, 2]. Hantaviruses are capable of causing serious diseases in humans, i.e. the so-called hantavirus fevers [3] that are defined as natural focus nontransmissible viral zoonoses. Hemorrhagic fever with renal syndrome (HFRS) is quite widespread in Eurasia, whereas hantavirus pulmonary syndrome (HPS) can be found in both North and South America. Geographic distribution and epidemiology of cases caused by hantaviruses are seen as the consequence of distribution and natural history of their natural hosts [4]. The problem with HFRS, associated with immunologically distinct hantaviruses, seems to be particularly acute on the foci where two or more of its causative agents are present at the same time. In the European part of Russia, the following hantaviruses are HFRS etiologic agents: Puumala (reservoir - the Myodes glareolus bank vole) and Dobrava (the Kurkino genetic subtype, the reservoir being a subspecies of the Apodemus agrarius field mouse and the Sochi genetic subtype, its reservoir being the Caucasian forest mouse A. ponticus) $[3,5,6]$. In the Asian part of Russia, the following hantaviruses are HFRS etiologic agents: Hantaan (Far East genovariant), Amur (Amursk, Khabarovsk, Primorye, and Primorye1-China genovariants) and Seoul (VDV genovariant). The natural hosts of Hantaan, Amur and Seoul viruses are the eastern subtype of the A. agrarius field mouse, A. peninsulae forest Asian mouse and Rattus norvegicus gray rat, respectively [7-9]. The forest ecosystems are dominated by A. peninsulae - the natural host of the Amur pathogenic virus and the source of infection to humans, its co-dominant being the Myodes rufocanus gray-sided vole - natural host of the Hokkaido hantavirus with an unknown virulence level to humans. Studying of the areas being endemic to HFRS is aimed at establishing biocenotic structures of ecosystems, function and reservoir potential peculiarities of hantavirus natural foci $[10,11]$. However, quite a few urgent issues 
related to natural foci of hantavirus zoonoses have not been thoroughly studied so far, one of them being the mechanism of epizootic activity in the dynamics of rodent population as well as epidemic manifestations of different types of hantavirus infection natural foci within a particular spatial-temporal framework. The purpose of the study was to determine the indicators of epizootic activity and their threshold values in the population dynamics of rodents, being the carriers of the forest areas hantaviruses, in order to predict HFRS incidence rise on the forested territory of Primorsky Krai.

\section{Material and Research methods}

For the purposes of the study the research material was obtained during field and stationary research activities (2001-2013) on the HFRS endemic areas in the belt of mixed coniferous-deciduous and deciduous forests in central and southern parts of Primorsky Krai. The epizootological observation and collection of the material was carried out yearly in spring, summer and autumn. During the observation period, 33890 trap-nights (TN) were worked over. 4594 rodents were caught, 2737 of those were identified as A. peninsulae, 214 - A. agrarius, 1505 - M. rufocanus, 114 - Myodes rutilus red voles and 24 - Microtus fortis reed voles.

Table 1 .

Immunological and molecular genetic research techniques

\begin{tabular}{|c|c|}
\hline Research techniques & $\begin{array}{l}\text { Hantavirus and infection } \\
\text { identification in rodents }\end{array}$ \\
\hline $\begin{array}{l}\text { ELISA (enzyme-linked immunosorbent assay) } \\
\text { Hantagnost commercial test-system manufactured by } \\
\text { Federal State Unitary Enterprise on Manufacture of } \\
\text { Bacterial and Viral Preparations of Chumakov Institute } \\
\text { of Poliomyelitis and Viral Encephalitides }\end{array}$ & $\begin{array}{l}\text { Viral antigen in } 10-20 \% \\
\text { of the rodents' lungs and } \\
\text { excretory organs suspen- } \\
\text { sion }\end{array}$ \\
\hline $\begin{array}{l}\text { RT-PCR (Reverse transcription polymerase chain reac- } \\
\text { tion) RNA extraction, RT and PCR formulation, visual } \\
\text { indication of amplification products by gel electropho- } \\
\text { resis in agarose gel in the presence of ethidium bromide. } \\
\text { Vector-Best, AmpliSens Hantavirus sets. }\end{array}$ & $\begin{array}{l}\text { Hantavirus RNA in the } \\
\text { animals' organs on ambi- } \\
\text { ent substrata }\end{array}$ \\
\hline $\begin{array}{l}\text { IFAT (Indirect fluorescent antibody technique). } \\
\text { Anti-species FITC conjugates manufactured by N.F. } \\
\text { Gamaleya Research Institute of Epidemiology and Mi- } \\
\text { crobiology. Antibody avidity in seropositive animals by } \\
\text { the Hedman technique (1991). }\end{array}$ & $\begin{array}{l}\text { Antibodies to culture anti- } \\
\text { gens of hantaviruses } \\
\text { Antibodies avidity: high, } \\
\text { transitional, low. }\end{array}$ \\
\hline
\end{tabular}


The animals' hantavirus infection was detected by the presence of antigen/ RNA in lungs/excretory organs and/or the presence of specific antibodies in their blood. Hantavirus antigen was identified using the ELISA, whereas viral RNA was identified using the RT-PCR; specific antibodies and their avidity were identified using the indirect fluorescence technique (Table 1).

To characterize hantavirus infection in individuals as well as on the population level of rodents, being hantavirus carriers, the following parameters and indicators were proposed: infection rate; acute infection; relative abundance / infection rate; epizootic activity (Table 2).

Table 2.

Main parameters and indicators of hantavirus infection

\begin{tabular}{|l|l|}
\hline \multicolumn{1}{|c|}{ Parameters and values } & \begin{tabular}{l} 
Hantavirus infection in animals and population \\
\hline Infection rate in rodents \\
antibodies in blood.
\end{tabular} \\
\hline $\begin{array}{l}\text { Acute infection in rodents (han- } \\
\text { tavirus shedding with the natural } \\
\text { host's saliva, urine, faeces into } \\
\text { ambient environment). }\end{array}$ & $\begin{array}{l}\text { Hantavirus antigen/RNA in lungs/ secretory } \\
\text { and excretory organs, antibodies of low/transi- } \\
\text { tional avidity. }\end{array}$ \\
\hline $\begin{array}{l}\text { Relative abundance of the species - } \\
\text { Relative infection rate - } \\
\text { Relatively acute infection - }\end{array}$ & $\begin{array}{l}\text { number of all individuals per 100 TN } \\
\text { number of all infected individuals per 100 TN } \\
\text { number of all individuals with acute infection } \\
\text { per 100 TN }\end{array}$ \\
\hline Epizootic activity & Relatively acute infection in population \\
\hline
\end{tabular}

\section{Research results and discussion}

Forest ecosystems occupy about $70 \%$ of Primorsky Krai. Amur viral infection endemic areas were identified in the parts of the region with mixed coniferous-deciduous forests with a high proportion of cedar and oak, and a well-developed lower tier, being a favorable habitat for the large Japanese field mouse. Amur viral infection active natural foci are located on the western and eastern slopes of the Sikhote-Alin ridge occupied by coniferous-deciduous forests that are preferred by the $A$. peninsulae. Long-time average annual values for various rodent species, being hantavirus carriers, in forest communities are shown in Table 3, which proves the fact that all the values obtained are much higher in the A. peninsulae species.

According to the obtained data the dynamics of epizootic activity in A. peninsulae populations has an expressed cyclic recurrence. Rise and high activity are valid up to a year, from autumn of the current year till autumn of the subsequent 
year, followed by recession. The phase of recession/low activity lasts for several years, determining the duration of the cycle. Table 4 presents the characteristic of the rodents, being hantaviruses carriers in forest ecosystems, within the phases of rise, high and low epizootic activity in A. peninsulae populations.

Table 3.

Long-time average annual values for rodents, being hantavirus carriers, in HFRS forest natural foci

\begin{tabular}{|l|c|c|c|c|}
\hline \multirow{2}{*}{$\begin{array}{c}\text { Species of rodents } \\
\text { as hantaviruses } \\
\text { carriers }\end{array}$} & $\begin{array}{c}\text { Species pro- } \\
\text { portion in } \\
\text { the trapping } \\
\text { (\%) }\end{array}$ & $\begin{array}{c}\text { Species proportion } \\
\text { of the infected } \\
\text { animals in the trap- } \\
\text { ping (\%) }\end{array}$ & $\begin{array}{c}\text { Species } \\
\text { popula- } \\
\text { tion (per } \\
100 \text { TN) }\end{array}$ & $\begin{array}{c}\text { The infection } \\
\text { rate of the spe- } \\
\text { cies (per 100 } \\
\text { TN) }\end{array}$ \\
\hline $\begin{array}{l}\text { Apodemus } \\
\text { peninsulae }\end{array}$ & $59,6 \pm 0,7$ & $\mathbf{6 5 , 5} \pm 1,8$ & $\mathbf{8 , 1}$ & $\mathbf{1 , 4}$ \\
\hline Apodemus agrarius & $4,7 \pm 0,2$ & $2,5 \pm 0,2$ & 0,6 & $<0,1$ \\
\hline Myodes rufocanus & $32,7 \pm 0,7$ & $29,6 \pm 0,5$ & 4,4 & 0,6 \\
\hline Microtus fortis & $0,5 \pm 0,1$ & $1,1 \pm 0,4$ & $<0,1$ & $<0,1$ \\
\hline Myodes rutilus & $2,5 \pm 0,2$ & $1,3 \pm 0,4$ & 0,3 & $<0,1$ \\
\hline
\end{tabular}

Table 4.

The characteristic of rodents, being hantaviruses carriers in forest ecosystems, within different phases of the epizootic activity in $A$. peninsulae populations

\begin{tabular}{|c|l|c|c|c|c|}
\hline \multirow{2}{*}{$\begin{array}{c}\text { Phases of } \\
\text { the } \text { A. penin- } \\
\text { sulae epizo- } \\
\text { otic cycle }\end{array}$} & $\begin{array}{c}\text { Species of rodents } \\
\text { as hantaviruses } \\
\text { carriers }\end{array}$ & $\begin{array}{c}\text { Values of the species } \\
\text { tion in the } \\
\text { trapping } \\
(\%)\end{array}$ & $\begin{array}{c}\text { Proportion of } \\
\text { the infected } \\
\text { animals in the } \\
\text { trapping } \\
(\%)\end{array}$ & $\begin{array}{c}\text { Popula- } \\
\text { tion (per } \\
100 \text { TN) }\end{array}$ & $\begin{array}{c}\text { The infec- } \\
\text { tion rate } \\
\text { (per } 100 \\
\text { TN) }\end{array}$ \\
\hline \multirow{5}{*}{ Phase I- } & A. peninsulae & $\mathbf{7 8 , 3}$ & $\mathbf{7 8 , 9}$ & $\mathbf{7 , 4 5}$ & $1, \mathbf{5 8}$ \\
activity rise & A. agrarius & 8,0 & 5,3 & 0,76 & 0,10 \\
& M. rufocanus & 13,4 & 15,8 & 1,28 & 1,31 \\
& Microtus fortis & 0,0 & 0,0 & 0,00 & 0,00 \\
& M. rutilus & 0,4 & 0,0 & 0,04 & 0,00 \\
\hline & A. peninsulae & $\mathbf{6 5 , 2}$ & $\mathbf{7 5 , 6}$ & $\mathbf{2 0 , 5 2}$ & $\mathbf{5 , 6 2}$ \\
Phase II- & A. agrarius & 3,3 & 1,8 & 1,04 & 0,14 \\
& M. rufocanus & 31,2 & 22,3 & 9,82 & 1,66 \\
& Microtus fortis & 0,2 & 0,3 & 0,07 & 0,02 \\
& M. rutilus & 0,1 & 0,0 & 0,02 & 0,00 \\
\hline
\end{tabular}


End of the Table 4.

\begin{tabular}{|c|l|c|c|c|c|}
\hline & A. peninsulae & $\mathbf{8 2 , 5}$ & $\mathbf{6 5 , 4}$ & $\mathbf{5 , 3 5}$ & $\mathbf{0 , 3 1}$ \\
Phase III- & A. agrarius & 1,0 & 0,0 & 0,06 & 0,00 \\
low activity & M. rufocanus & 13,5 & 26,9 & 0,88 & 0,15 \\
& Microtus fortis & 0,3 & 3,8 & 0,02 & 0,02 \\
& M. rutilus & 2,6 & 3,8 & 0,17 & 0,02 \\
\hline
\end{tabular}

During a year characterized by the activity rise the relative abundance of mice with acute infection in populations of $A$. peninsulae increased from summer to late autumn to an average value of 2 . Within the high activity phase the number of mice with acute infection during a spring and summer season was more than 5 individuals per $100 \mathrm{TN}$, decreasing to more than 3 times in autumn at a fairly high population rate. Within the phase of low epizootic activity individuals with acute infection were found during all seasons, their number not exceeding the value of 0.3 .

As a result of HFRS forest foci long-term monitoring, the parameters of hantaviruses active circulation were determined as well as their threshold values at different phases of the epizootic cycle in populations of rodents, being virus carriers, were defined. As seen in Table 5, within all the cycle phases the epizootic activity values tend to be much higher in $A$. peninsulae, compared to $M$. rufocanus, that proves the epidemiological importance of this species in forest ecosystems of Primorsky Krai.

Table 5

Threshold values of the population parameters within different phases of the Apodemus peninsulae and Myodes rufocanus epizootic cycle

\begin{tabular}{|c|c|c|c|c|}
\hline Parameters & \multicolumn{2}{|c|}{ Phases of the cycle } & $\begin{array}{l}\text { Apodemus } \\
\text { peninsulae }\end{array}$ & $\begin{array}{l}\text { Myodes } \\
\text { rufocanus }\end{array}$ \\
\hline \multirow{9}{*}{$\begin{array}{l}\text { Relative abundance of the } \\
\text { natural host (number of indi- } \\
\text { viduals per } 100 \mathrm{TN} \text { ): } \\
\mathbf{N} \text { - whole population } \\
\mathbf{n}_{u}-\text { all infected animals } \\
\mathbf{n}_{\text {ou }} \text { - animals with acute in- } \\
\text { fection }\end{array}$} & \multirow{3}{*}{$\begin{array}{l}\text { Rise of the epizo- } \\
\text { otic activity }\end{array}$} & $\mathbf{N}$ & $\geq 8,0$ & $\geq 1,5$ \\
\hline & & $\mathbf{n}_{u}$ & $\geq 1,8$ & $\geq 0,3$ \\
\hline & & $\mathbf{n}_{o u}$ & $\geq 1,5$ & $\geq 0,2$ \\
\hline & \multirow{3}{*}{$\begin{array}{l}\text { High epizootic } \\
\text { activity }\end{array}$} & $\mathbf{N}$ & $\geq 20,0$ & $\geq 9,0$ \\
\hline & & $\mathbf{n}_{u}$ & $\geq 7,0$ & $\geq 1,7$ \\
\hline & & $\mathbf{n}_{o u}$ & $\geq \mathbf{5 , 0}$ & $\geq 0,8$ \\
\hline & \multirow{3}{*}{$\begin{array}{l}\text { Low epizootic } \\
\text { activity }\end{array}$} & $\mathbf{N}$ & $\leq 6,0$ & $\leq 1,0$ \\
\hline & & $\mathbf{n}_{u}$ & $\leq 0.5$ & $\leq 0,2$ \\
\hline & & $\mathbf{n}_{o u}$ & $\leq \mathbf{0 , 3}$ & $\leq 0,1$ \\
\hline
\end{tabular}

For the observed period, in forest natural foci of hantavirus infection 39.6\% of HFRS cases were reported from May to June. During the years of high epizo- 
otic activity in the populations of the large Asian field mouse the bulk of HFRS cases were reported in spring and summer ( $68.6 \%$ of annual incidence). When comparing the long-time annual dynamic pattern of the epizootic activity in populations of rodents, being hantavirus carriers, to HFRS incidence in humans, the following dynamics conjugation was noted, the one of the epizootic process in populations of $A$. peninsulae and the annual and seasonal dynamics of HFRS cases registration. During the rise/high stage of the epizootic activity in populations of $A$. peninsulae two incidence peaks were determined: autumn to winter ( $\geq$ $37,5 \%$ of cases during a year), and spring to summer ( $\geq 55,2 \%$ of cases).

Another research activity was conducted within the frame of the study regarding the possibility to preserve natural foci of HFRS hantaviruses in the ambient environment, the ones excreted by the infected rodents with urine, saliva, faeces. Environmental substrata samples were taken on forested areas, being enzootic to hantavirus infections (Table 6).

Table 6.

Detection of hantavirus RNA, being external to its natural host, in the ambient environment of HFRS forest foci

\begin{tabular}{|l|l|c|c|c|}
\hline \multicolumn{1}{|c|}{$\begin{array}{c}\text { Area / Time of } \\
\text { sample collection }\end{array}$} & \multicolumn{1}{|c|}{ Research objects } & $\begin{array}{c}\text { Number of } \\
\text { substrara } \\
\text { samples }\end{array}$ & $\begin{array}{c}\text { Sample } \\
\text { charac- } \\
\text { teristics }\end{array}$ & $\begin{array}{c}\text { RT-PCR } \\
\text { results }\end{array}$ \\
\hline $\begin{array}{l}\text { Kavalerovsky } \\
\text { district, June to } \\
\text { October }\end{array}$ & $\begin{array}{l}\text { Trap lines in coniferous and } \\
\text { cone-bearing forest on a } \\
\text { stationary plot }\end{array}$ & 20 & $\begin{array}{l}\text { Soil with } \\
\text { plant } \\
\text { litter }\end{array}$ & $\begin{array}{c}\text { 4+ RNA } \\
\text { assays }\end{array}$ \\
\hline $\begin{array}{l}\text { Chuguyevsky dis- } \\
\text { trict, October }\end{array}$ & Rodents' natural refuges & 10 & $\begin{array}{l}\text { Soil with } \\
\text { litter }\end{array}$ & $\begin{array}{c}\text { 2+ RNA } \\
\text { assays }\end{array}$ \\
\hline $\begin{array}{l}\text { Olginsky district, } \\
\text { Jyne. HFRS group } \\
\text { cases }\end{array}$ & $\begin{array}{l}\text { Trap lines in coniferous and } \\
\text { cone-bearing forest around } \\
\text { gamekeepers'dwelling }\end{array}$ & 8 & $\begin{array}{l}\text { Soil with } \\
\text { plant } \\
\text { litter }\end{array}$ & $\begin{array}{c}\text { 2+ RNA } \\
\text { assays }\end{array}$ \\
\hline
\end{tabular}

A specific RNA was found in the samples containing soil with plant litter on trap lines as well as in places, where HFRS group cases had been detected, and a certain number of $A$. peninsulae with acute hantavirus infection had been caught as well as traces of their activity detected.

\section{Conclusion}

To date, the Eurasian countries have seen the increase in both the amplitude and number of HFRS outbreaks. The risk determinants include reservoir ecology, ecology of the virus and antropogenous factors $[12,13]$. Every year, 
hundreds of thousands of people, who live in the endemic territories or temporarily stay there while at work or having time off, get in contact with HFRS natural foci. Both temporary protection of an individual or a group of people from a pathogen is required, as well as preventive measures aimed at reducing infection rate on specific HFRS endemic territories. HFRS, having all the features of the emerging infection, can lead to a complicated epidemic situation. In some HFRS and HPS outbreaks the mortality rate can reach $12 \%$ and $60 \%$ respectively [14]. WHO estimates that each year there are between 150000 and 200000 hantavirus disease cases, of which 70 to $90 \%$ are detected in parts of China, adjoining the north-eastern border of Primorsky Krai. More and more HFRS cases are reported in Europe [15]. In order to improve the prevention of hantavirus infections, the cooperation of international organizations is required, just as it is done concerning other widespread viral diseases [16].

According to the hypothesis (Vorontsov, 1974), causative agents of viral infections, by integrating fragments of their genome into their natural host's genome, play an important role in their evolution. The strategy to prevent natural foci infection should be aimed at preserving the role of the pathogen in the ecosystem, along with the unconditional protection of humans from infections caused by pathogens, rather than at the elimination of the pathogen [17].

In order to develop effective methods of HFRS protection and prevention, in our opinion, it is necessary to obtain quantitative parameters of hantaviruses circulation in different phases of the epizootic cycle in different types of the natural foci. After long-term monitoring of HFRS forest foci in Primorsky Krai, certain epidemic-significant indicators and their thresholds values were identified that reflect the activity of the epizootic process in its different development phases in populations of A. peninsulae and M. rufocanus, being natural hosts to Amur and Hokkaido hantaviruses. It is important to note that the rise, high and low epizootic activity values obtained were significantly higher in $A$. peninsulae compared to $M$. rufocanus, that proves the former's epidemic significance. Within the periods of rise and high epizootic activity in populations of $A$. peninsulae the two HFRS incidence peaks were observed as follows: autumn to winter and spring to summer ( $\geq 37 \%$ and $\geq 55 \%$ of the annual incidence). The epizootic activity in populations of $A$. peninsulae, being cyclical, leads to years to year and seasonal differences in the HFRS cases distribution $[18,19]$. Detection of hantavirus RNA in ambient environment substrata of HFRS forest natural foci shows the possibility of Amur virus survival within a considerably long period, while being external of its natural host organism, which is consistent with the data obtained for Puumala hantavirus [20]. Considering the 'hantavirus - rodent' binomial par- 
asitic system the study on the detection of hantavirus in the medium between the natural host and human being seems to be quite significant in determining the factors, time, and areas of HFRS high infection rate concerning humans.

The proposed indicators for assessing the epizootic activity and their threshold values in the population dynamics of the natural host of Amur virus makes it possible to predict high-risk periods of human infection in HFRS forest foci within a particular spatial-temporal framework.

\section{References}

1. Mir M. Hantaviruses. Clin. Lab. Med., 2010, vol. 30, no. 1, pp. 67-91.

2. Castel G., Razzauti M., Jousselin E., Kergoat G.J., Cosson G.F. Changes in diversification patterns and signatures of selection during the evolution of murinae-associated hantaviruses. Viruses, 2014, vol. 10, no. 6 (3), pp.1112-34.

3. Tkachenko E.A., Bernshtejn A.D., Dzagurova T.K., Morozov V.G., Slonova R.A., Ivanov L.I., Trankvilevskij D.V., Krjuger D. Aktual'nye problemy sovremennogo jetapa izuchenija gemorragicheskoj lihoradkoj s pochechnym sindromom v Rossii [Actual issues of hemorrhagic fever with renal syndrome]. Zh. Mikrobiol., jepidemiol., immunobiol. [Zh. Microbiol. (Moscow)], 2013, no 1, pp. 51-58.

4. Plyusnin A., Morzunov S. Virus evolution and genetic diversity of hantaviruses rodent hosts. Curr. Top. Microbiol. Immunol., 2001, vol. 256, pp. 47-75.

5. Dzagurova T.K. Gemorragicheskaja lihoradka s pochechnym sindromom (jetiologija, specificheskaja laboratornaja diagnostika, razrabotka diagnosticheskih $i$ vakcinnyh preparatov) [Hemorrhagic fever with renal syndrome (etiology, specific laboratory diagnostics, development of diagnostic and vaccinic preparations)]: Avtoref. dis. ... d-ra med. nauk. Moscow, 2014. 47 p.

6. Klempa B., Avsic-Zupanc T., Clement J., Dzagurova T.K., Henttonen H., Jakab F., Kruger D.H., Maes P., PapaA., Tkachenko E.A., Ulrich L.G., Vapalahti O., Vaheri A. Complex evolution and epidemiology of Dobrava-Belgrade hantavirus: definition of genotipes and their characteristics. Arch Virology., 2013, vol. 158 , no. 3, pp. 521-529.

7. Slonova R.A., Kushnareva T.V., Kompanec G.G., MaksemaI.G., Simonova T.L., Simonov S.B. Hantavirusnaja infekcija v Primorskom krae - jepidemiologicheskaja situacija $\mathrm{v}$ ochagah cirkuljacii raznyh serotipov virusa [Hantavirus infection in Primorye - epidemiologic conditions in the nidi of circulation of different serotypes of virus]. Zh. Mikrobiol., jepidemiol. i immunobiol. [Zh. Microbiol. (Moscow)], 2006, no3, pp. 74-77.

8. Jashina L.N. Geneticheskoe raznoobrazie hantavirusov v populjacijah gryzunov i nasekomojadnyh aziatskoj chasti Rossii [Genetic diversity of Hantaviruses 
in Rodent and Insectivora populations of Russia Asiatic part]: Avtoref. dis. ... d-ra biol. nauk: Novosibirsk, 2012. 49 p.

9. Kushnareva T.V. New aspects of ecology of hantaviruses and hantaviral infections. Eastern European Scientific J., 2016, no. 1, pp. 21-26.

10. Nafeev A.A., Shemjatihina G.B. Jekologo-jepidemiologicheskie podhody k nadzoru za gemorragicheskoj lihoradkoj s pochechnym sindromom [Ecological and epidemiological approaches to the control of hemorrhagic fever with renal syndrome]. Jepidemiologija i infekcionnye bolezni [Epidemiol. Infect. Dis. (Moscow)], 2011, no 1, pp. 49-50.

11. Tersago K., Verhagen R., Leirs H. Temporal variation in individual factors associated with hantavirus infection in bank voles during an epizootic: implications for Puumala virus transmission dynamics. Vector Borne Zoonotic Dis., 2011, vol. 11, pp. 715-721.

12. Dearing M., Dizney L. Ecology of hantavirus in a changing world. Ann. Ny. Acad. Sci., 2010, vol. 1195, pp. 99-112.

13. Zhigal'skij O.A., Bernshtejn A.D., Kshnjasev I.A., Apekina N.S. Jekologicheskie mehanizmy funkcionirovanija aktivnyh evropejskih ochagov GLPS [Ecological mechanisms of function of active European HFRS foci]. Jekologija [Ecology (Moscow)], 2013, no 3, pp. 237-240.

14. Jonsson C.B., Figueiredo L.T.M., Vapalahti O.A. Global Perspective on Hantavirus Ecology, Epidemiology and Disease. Clin. Microbiol. Rev., 2010, vol. 23, no. 2, pp. 412-441.

15. Manigold T., Vial P. Human hantavirus infections: epidemiology, clinical features, pathogenesis and immunology. Swiss Medical Weekly, 2014, vol. 144, w. 13937.

16. Mamaev T.M., Zholdoshev S.T., Durusbekov A.D., Mamadzhanov A.N. Strategija profilaktiki VICh-infekcii v Oshskoj oblasti Kyrgyzskoj respubliki [Strategy of prevention of HIV in the Osh region of the Kyrgyz republic]. V mire nauchnyh otkrytij [In the world of Scientific Discoveries], 2016, no. 2 (74), pp. 120-130.

17. Korenberg Je.I. Prirodnaja ochagovost' infekcij: sovremennye problemy i perspektivy issledovanija [Natural focality of infections: current problems and prospects of investigations]. Zoologicheskij Zh. [Zoological J. (Moscow)], 2010, vol. 89, no. 1, pp. 5-17.

18. Slonova R.A., Kushnareva T.V., Kompanec G.G., Maksema I.G., Iunihina O.V., Kushnarev E.L. Svjaz' jepidemicheskogo processa hantavirusnoj infekcii s jepizooticheskim processom v populjacijah myshej roda Apodemus [Relationship of epidemic of hantavirus infection with epizootic process in mice populations of genus Apodemus]. Tihookeanskij medicinskij Zh. [Pasific Medical J.], 2010, no. 3, pp. 34-37. 
19. Kushnareva T.V., Slonova R.A. Rezervuarnyj potencial prirodnyh hozjaev hantavirusov v dinamike jepizooticheskogo processa v jekosistemah Primorskogo kraja [Reservoir potential of hantavirus natural hosts in the epizootic process dynamic in the ecosystems of Primorskii Krai]. Sibirskij jekologicheskij Zh. [Siberian Ecological J.], 2014, no. 1, pp. 27-34. [Kushnareva T.V., Slonova R.A. The Natural Host Range of Hantaviruses and Their Reservoir Potential in the Dynamic of the Epizootic Process within the Ecosystems of Primorskii Krai . Contemporary Problems of Ecology, 2014, vol. 7, iss. 1, pp. 19-25].

20. Kallio E.R., Klingstrum J., Gustafsson E., Manni T., Vaheri A., Henttonen H., Vapalahti O., Lundkvist A. Prolonget survival of Puumala hantavirus outside the host: evidence for indirect transmission via the environment. J. Gen. Virol., 2006, vol. 87, no. 8, pp. 2127-2134.

\section{Список литературы}

1. Mir M. Hantaviruses // Clin. Lab. Med. 2010. Vol. 30. N. 1, pp. 67-91.

2. Changes in diversification patterns and signatures of selection during the evolution of murinae-associated hantaviruses / G. Castel, M. Razzauti, E. Jousselin, G.J. Kergoat, J.F. Cosson // Viruses. 2014. Vol. 10. N 6 (3), pp. 1112-1134.

3. Актуальные проблемы современного этапа изучения геморрагической лихорадкой с почечным синдромом в России / Е.А. Ткаченко, А.Д. Бернштейн, Т.К. Дзагурова, В.Г. Морозов, Р.А. Слонова, Л.И. Иванов, Д.В. Транквилевский, Д. Крюгер // Ж. микробиол., эпидемиол. и иммунобиол., 2013. № 1. С. 51-58.

4. Plyusnin A., Morzunov S. Virus evolution and genetic diversity of hantaviruses rodent hosts // Curr. Top. Microbiol. Immunol. 2001. Vol. 256, pp. 47-75.

5. Дзагурова Т.К. Геморрагическая лихорадка с почечным синдромом (этиология, специфическая лабораторная диагностика, разработка диагностических и вакцинных препаратов): автореф. дис. ... д-ра мед. наук. М., 2014. 47 с.

6. Complex evolution and epidemiology of Dobrava-Belgrade hantavirus: definition of genotipes and their characteristics / B. Klempa, T. Avsic-Zupanc, J. Clement, T.K. Dzagurova, H. Henttonen, F. Jakab, D.H. Kruger, P. Maes, A. Papa, E.A. Tkachenko, L.G. Ulrich, O. Vapalahti, A. Vaheri // Arch Virology. 2013. Vol. 158. N. 3, pp. 521-529.

7. Хантавирусная инфекция в Приморском крае - эпидемиологическая ситуация в очагах циркуляции разных серотипов вируса / Р.А. Слонова, Т.В. Кушнарева, Г.Г. Компанец, И.Г. Максема, Т.Л. Симонова, С.Б. Симонов // Ж. микробиол., эпидемиол. и иммунобиол., 2006. № 3. С. 74-77.

8. Яшина Л.Н. Генетическое разнообразие хантавирусов в популяциях грызунов и насекомоядных азиатской части России: автореф. дис. ... д-ра биол. наук. Новосибирск, 2012. 49. 
9. Kushnareva T.V. New aspects of ecology of hantaviruses and hantaviral infections // Eastern European Scientific J. 2016. N.1, pp. 21-26.

10. Нафеев А.А., Шемятихина Г.Б. Эколого-эпидемиологические подходы к надзору за геморрагической лихорадкой с почечным синдромом // Эпидемиология и инфекционные болезни. 2011. № 1. С. 49-50.

11. Tersago K., Verhagen R., Leirs H. Temporal variation in individual factors associated with hantavirus infection in bank voles during an epizootic: implications for Puumala virus transmission dynamics // Vector Borne Zoonotic Dis. 2011. Vol. 11, pp. 715-721.

12. Dearing M., Dizney L. Ecology of hantavirus in a changing world // Ann. Ny. Acad. Sci. 2010. Vol. 1195, pp. 99-112.

13. Экологические механизмы функционирования активных европейских очагов ГЛПС / О.А. Жигальский, А.Д. Бернштейн, И.А. Кшнясев, Н.С. Апекина // Экология. 2013. № 3. С. 237-240.

14. Jonsson C.B., Figueiredo L.T.M., Vapalahti O.A. Global Perspective on Hantavirus Ecology, Epidemiology and Disease // Clin. Microbiol. Rev. 2010. Vol. 23. N 2, pp. 412-441.

15. Manigold T., Vial P. Human hantavirus infections: epidemiology, clinical features, pathogenesis and immunology // Swiss Medical Weekly. 2014. Vol. 144. W. 13937.

16. Стратегия профилактики ВИЧ-инфекции в Ошской области Кыргызской республики / Т.М. Мамаев, С.Т. Жолдошев, А.Д. Дурусбеков, А.Н. Мамаджанов // В мире научных открытий. 2016. 2 (74). С. 120-130.

17. Коренберг Э.И. Природная очаговость инфекций: современные проблемы и перспективы исследования // Зоологич. Ж. 2010. Т. 89. № 1. С. 5-17.

18. Связь эпидемического процесса хантавирусной инфекции с эпизоотическим процессом в популяциях мышей рода Apodemus / Р.А. Слонова, Т.В. Кушнарева, Г.Г. Компанец, И.Г. Максема, О.В. Иунихина, Е.Л. Кушнарев // Тихоокеанский Медицинский Ж. 2010. № 3. С. 34-37.

19. Кушнарева Т.В., Слонова Р.А. Резервуарный потенциал природных хозяев хантавирусов в динамике эпизоотического процесса в экосистемах Приморского края // Сибирский Экологический Ж. 2014. № 1. С. 27-34. [Kushnareva T.V., Slonova R.A. The Natural Host Range of Hantaviruses and Their Reservoir Potential in the Dynamic of the Epizootic Process within the Ecosystems of Primorskii Krai // Contemporary Problems of Ecology. 2014. Vol. 7. Iss. 1, pp. 19-25]. (http://link.springer.com/article/10.1134/S1995425514010090).

20. Prolonget survival of Puumala hantavirus outside the host: evidence for indirect transmission via the environment / T.R. Kallio, J. Klingstrum, E. Gustafs- 
son, T. Manni, A. Vaheri, H. Henttonen, O. Vapalahti, A. Lundkvist // J. Gen. Virol. 2006. Vol. 87. N. 8, pp. 2127-2134.

\section{DATA ABOUT THE AUTHORS}

Kushnareva Tatyana Valerevna, Leading Scientist of Hantaviral Infections Laboratory, Candidate of Biology Science

Institution of Epidemiology and Microbiology name of G.P. Somov; Pacific State Medical University

1, Selskaya Str., Vladivostok, Primorskii Krai, 690087, Russian Federation; 2, Ostryakova av., Vladivostok, 690002, Russian Federation tatyana.kushnareva@inbox.ru

SPIN-code: 2345-7935

ORCID: 0000-0002-9629-1281

ResearcherID: I-8451-2016

Kumaksheva Elizaveta Vladimirovna, Junior Scientist of Hantaviral Infections Laboratory

Institution of Epidemiology and Microbiology name of G.P. Somov

1, Selskaya Str., Vladivostok, Primorskii Krai, 690087, Russian Federation

liza_kumaksheva@mail.ru

\section{ДАННЫЕ ОБ АВТОРАХ}

Кушнарева Татьяна Валерьевна, ведущий научный сотрудник лаборатории хантавирусных инфекций, кандидат биологических наук НИИ эпидемиологии и микробиологии имени Г.П. Сомова; Тихоокеанский государственный медицинский университет

ул. Сельская, 1, г. Владивосток, Приморский край, 690087, Российская Федерация; пр. Острякова, 2, г. Владивосток, приморский край, 690002, Российская Федерация tatyana.kushnareva@inbox.ru

Кумакшева Елизавета Владимировна, младший научный сотрудник лаборатории ХВИ НИИ эпидемиологии и микробиологии имени Г.П. Сомова ул. Сельская, 1, г. Владивосток, Приморский край, 690087, Российская Федерачия liza_kumaksheva@mail.ru 